\title{
Performance Analysis of 210 Mw at NTPC Vindhyachal, Singrauli
}

\author{
Sadhana Singh ${ }^{+*}$, Savita Vyas ${ }^{* *}$ and Snehesh Banerjee ${ }^{\#}$ \\ †School of Energy \& Environment Management, Rajiv Gandhi Proudyogiki Vishwavidyalaya Bhopal, Madhya Pradesh, India \\ \#National Thermal Power Corporation Ltd., Vindhyachal Madhya Pradesh, India
}

Accepted 02 Jan 2017, Available online 13 Jan 2017, Vol.7, No.1 (Feb 2017)

\begin{abstract}
In India, coal is the dominant source of energy generation. Efficiency of any conventional coal fired unit ranges from 34-38\%. This paper presents the efficiency calculation of boiler, turbine and condenser of a $210 \mathrm{MW}$ unit. The study focuses on evaluation of various parameters like dry flue gas loss, wet flue gas loss, moisture in fuel and hydrogen, condenser back pressure, turbine cylinder efficiency, soot formation, etc. and some optimization techniques are mentioned to minimize the same. The benefits of these techniques are considerable fuel saving, emission reduction, heat rate improvement, cost minimization, increased equipment life cycle, etc. Cost analysis through heat rate deviation has been done to determine annual fuel savings. Lastly various critical parameters are mentioned for further improvement of plant performance
\end{abstract}

Keywords: Coal fired power plant, rankine cycle, boiler efficiency, turbine efficiency, condenser efficiency, heat rate

\section{Introduction}

${ }^{1}$ The proposed power station NTPC, Vindhyachal located in Singrauli district of Madhya Pradesh has capacity of 4760 MW. This plant constitutes of $6 \times 210 \mathrm{MW}$ units and $7 \times 500 \mathrm{MW}$ units. The performance evaluation in this paper is carried out on unit no. 4 of stage 1. [NTPC manual et al, 2016]

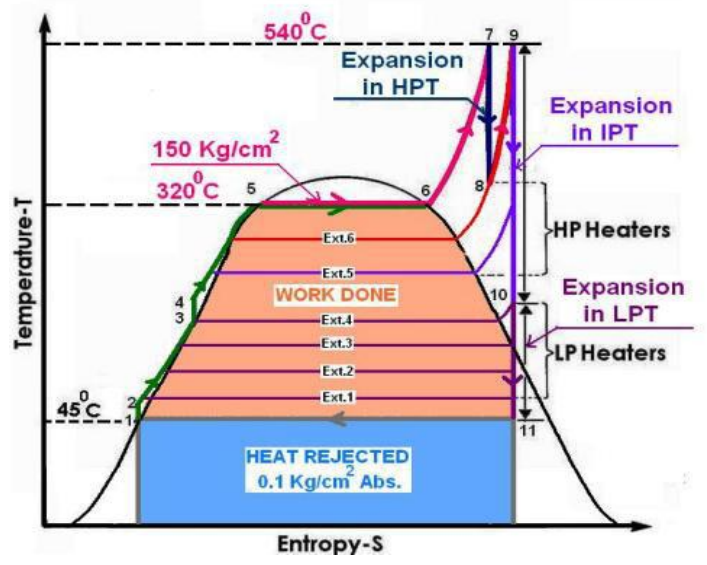

Figure 1 Modified Rankine Cycle

It works on the principle of modified rankine cycle. The function of thermal power plant is to generate steam in boiler which is used to drive turbine and generator mounted on the same shaft to produce electricity. The exhaust from low pressure turbine is condensed in condenser and the resultant condensate is extracted through condensate extraction pump. This condensate is then sent back to boiler through boiler feed pump via low pressure and high pressure heaters. [Nag P.K. et al, 2002].

The CEA in India uses power station heat rate as a proxy for calculating plant efficiency. The heat rate of a power plant is the amount of chemical energy that must be supplied to produce one unit of electrical energy. Some of the heat rate factors that affect power plant performance are ageing of machine, coal quality, plant load factor, operating margins, initial plant design, etc.

\section{Methodology \\ 2.1 Performance Of Boiler}

Boiler is an enclosed pressure vessel where heat generated by combustion of fuel is transferred to water to become steam. Boiler efficiency is defined as the heat added to the working fluid expressed as a percentage of heat in the fuel being burnt.

\subsubsection{Direct Method}

The energy gain of the working fluid (water and steam) is compared with the energy content of the boiler fuel. 
Where,

hg- Enthalpy of saturated steam in $\mathrm{kCal} / \mathrm{kg}$ of steam

$\mathrm{h}_{\mathrm{f}}$ - Enthalpy of feed water in $\mathrm{kCal} / \mathrm{kg}$ of water

$\mathrm{Q}$ - Quantity of steam generated per hour (Q) in $\mathrm{kg} / \mathrm{hr}$.

q- Quantity of fuel used per hour (q) in $\mathrm{kg} / \mathrm{hr}$

GCV - gross calorific value of the fuel in $\mathrm{kCal} / \mathrm{kg}$ of fuel [Shah et al, 2011].



[Sethi V.K. et al, 2012]

\subsubsection{Indirect Method or Heat Loss Method:}

The efficiency is the difference between the losses and the energy input.

The main advantage of indirect method is that the errors obtained from this method do not make any major change in the efficiency. [Shankar B.S.S et al, 2015].

Thus if boiler efficiency is $90 \%$ an error of $1 \%$ in direct method will result in significant change is efficiency, i.e.

$90 \mathrm{C} \pm 0.9=89.1$ to 90.9

Whereas in indirect method, $1 \%$ error in measurement of losses will result in;

Efficiency $=100-(10 \pm 0.1)$

$=90 \pm 0.1=89.9$ to 90.1 [Sethi V.K. et al, 2012]

Accountable losses in coal fired boilers are

Heat loss due to dry flue gas as sensible heat (L1)

- Un-burnt losses in bottom ash as carbon (L2).

- Heat loss due to moisture in the coal (L3).

- Heat loss due to moisture from burning of hydrogen in coal (L4).

- Heat loss due to moisture in air (L5).

- Heat loss due to incomplete combustion of carbon (L6)

- Loss due to surface radiation and convection (L7). [Dhanre et al, 2014]

Theoretical air requirement $=$

$\underline{\left[(11.6 \times \mathrm{C})+\left\{34.8 \times\left(\mathrm{H}_{2}-\mathrm{O}_{2} / 8\right)\right\}+(4.35 \times \mathrm{S})\right.}$

$\frac{\mathrm{Kg}}{\mathrm{Kg}}$ of fuel
Excess air supplied $=\frac{\mathrm{O}_{2} \%}{21-\mathrm{O}_{2} \%} \times 100$

Actual mass of air supplied $/ \mathrm{kg}$ of fuel (AAS)

$=\left\{1+\frac{E A}{100}\right\} \times$ Theoretical air

1) Percentage heat loss due to dry flue gas $=\frac{\mathrm{m} \times \mathrm{C}_{\mathrm{p}} \times\left(\mathrm{T}_{\left.\mathrm{f}-\mathrm{T}_{\mathrm{a}}\right)}\right.}{\mathrm{GCV} \text { of fuel }} \times 100$

Where;

$\mathrm{m}=$ mass of dry flue gas in $\mathrm{kg} / \mathrm{kg}$ of fuel

$\mathrm{C}_{\mathrm{p}}=$ Specific heat of flue gas $\left(0.23 \mathrm{kcal} / \mathrm{kg}{ }^{0} \mathrm{C}\right)$

2) Percentage heat loss due to unburnt carbon in

bottom ash

$=\frac{\text { Total ash collected } / \mathrm{kg} \text { of fuel burnt } \times \mathrm{GCV} \text { of bottom ash }}{\text { GCV of fuel }} \times 100$

3) Percentage heat loss due to evaporation of moisture present in fuel

$=\frac{\mathrm{M} \times\left\{584+\mathrm{C}_{\mathrm{P}}\left(\mathrm{T}_{\mathrm{f}}-\mathrm{T}_{\mathrm{a}}\right)\right\}}{\mathrm{GCV} \text { of fuel }} \times 100$

Where

$\mathrm{M}-\mathrm{kg}$ of moisture in $1 \mathrm{~kg}$ of fuel

$\mathrm{C}_{\mathrm{p}}$ - Specific heat of superheated steam

$(0.45 \mathrm{kcal} / \mathrm{kg})^{0} \mathrm{C}$

* 584 is the latent heat corresponding to the partial pressure of water vapour.

4) Percentage heat loss due to evaporation of water formed due to $\mathrm{H}_{2}$ in fuel $=\frac{9 \times H_{2} \times\left\{584+C_{P}\left(T_{f}-T_{a}\right)\right\}}{G C V \text { of fuel }} \times 100$ Where,

$\mathrm{H}_{2}-\mathrm{kg}$ of $\mathrm{H}_{2}$ in $1 \mathrm{~kg}$ of fuel

$\mathrm{C}_{\mathrm{p}}$ - Specific heat of superheated steam

$\left(0.45 \mathrm{kcal} / \mathrm{kg}^{0} \mathrm{C}\right)$

5) Percentage heat loss due to moisture present in air $=\frac{\text { AAS } \times \text { humidity factor } \times \mathrm{C}_{\mathrm{P}} \times\left(\mathrm{T}_{\mathrm{f}}-\mathrm{T}_{\mathrm{a}}\right)}{\mathrm{GCV} \text { of fuel }} \times 100$

Where,

$\mathrm{C}_{\mathrm{p}}$ - Specific heat of superheated steam

$\left(0.45 \mathrm{kcal} / \mathrm{kg}^{0} \mathrm{C}\right)$ [Kurkiya et al, 2012]

6) Percentage heat loss due to incomplete combustion $L_{6}=\frac{\% \times C \times 5744}{\left(\% \mathrm{CO}+\% \mathrm{CO}_{2}\right) \times G C V \text { of coal }} \times 100$

Where,

L5 $=\%$ Heat loss due to partial conversion of $\mathrm{C}$ to $\mathrm{CO}$

$\mathrm{CO}=$ Volume of $\mathrm{CO}$ in flue gas leaving economizer $(\%)$

$\mathrm{CO} 2$ = Actual Volume of CO2 in flue gas (\%)

$\mathrm{C}=$ Carbon content $\mathrm{kg} / \mathrm{kg}$ of fuel [Kumar et al, 2013]

7) Percentage heat loss due to radiation and other unaccounted loss

Unaccounted losses include losses from boiler casing to surrounding, loss due to combination of carbon and water, heat carried away in ash, losses due to un-burnt volatile matter, heat loss due to bottom seal water. Radiation loss depends on the effectiveness of the boiler casing insulation. [Sethi V.K. et al, 2012] 
In a relatively small boiler, with a capacity of $10 \mathrm{MW}$, the radiation and unaccounted losses could amount to between $1 \%$ and $2 \%$ of the gross calorific value of the fuel, while in a $500 \mathrm{MW}$ boiler, values between $0.2 \%$ to $1 \%$ are typical. The loss may be assumed appropriately depending on the surface condition.

Boiler efficiency $(\eta)=100-(1+2+3+4+5+6+7)$ [Kurkiya et al, 2012]

Table1 Losses in boiler by indirect method

\begin{tabular}{|c|c|c|c|}
\hline S1. No. & $\begin{array}{c}\text { Heat losses } \\
\text { (\%) }\end{array}$ & Design & Corrected \\
\hline 1. & L1 & 4.46 & 5.38 \\
\hline 2. & L2 & 0.49 & 0.63 \\
\hline 3. & L3 & 2.64 & 2.68 \\
\hline 4. & L4 & 3.49 & 3.54 \\
\hline 5. & L5 & 0.13 & 0.16 \\
\hline 6. & L6 & 0.02 & 0.02 \\
\hline 7. & L7 & 1.21 & 1.06 \\
\hline & П of boiler & 87.56 & 86.53 \\
\hline
\end{tabular}

\subsection{Performance of Turbine}

Steam turbine is a mechanical device that extracts thermal energy from pressurized steam, and converts it to useful mechanical work. The steam turbines are split into three separate stages, High Pressure (HP), Intermediate Pressure (IP) and Low Pressure (LP) stage, which are mounted on the same shaft along with generator. [Kumar et al, 2013].

Turbine efficiency is defined as the ratio of mechanical work output in kcal (or KJ) to the total heat available across the turbine in kcal (or kJ) expressed as a percentage. [Nag P.K. et al, 2002]

Following formulas are used for calculating turbine efficiency

1) Total accountable losses + Design heat rate $=$ Unit heat rate

2) Accountable losses of turbine + Design turbine heat rate $=$ Turbine heat rate

3) turbine cycle efficiency $=\frac{860}{\text { turbine heat rate }} \times 100$

Table 2 Heat rate deviation of different parameters

\begin{tabular}{|c|c|c|c|c|c|}
\hline Sl. No. & Particulars & Unit & Design & Operation & UHR Loss (Kcal/Kwh) \\
\hline 1. & Partial loading & $\%$ & & 0 & 0 \\
\hline 2. & $\begin{array}{l}\text { LPT. Exhaust steam temp } \\
\text { Cond. Backpressure }\end{array}$ & $\begin{array}{c}{ }^{\circ} \mathrm{C} \\
\mathrm{Ksc} \\
\end{array}$ & $\begin{array}{c}43.2 \\
0.089 \\
\end{array}$ & $\begin{array}{l}43.5 \\
0.91 \\
\end{array}$ & -2 \\
\hline 3. & D.M. make up & $\mathrm{T} / \mathrm{Hr}$ & & 6.25 & -11 \\
\hline 4. & Final F.W. temp. & ${ }^{\circ} \mathrm{C}$ & 247 & 251.44 & 0 \\
\hline 5. & R.H. spray & $\mathrm{T} / \mathrm{Hr}$ & 0 & 15.75 & -12 \\
\hline 6. & Main steam press. & $\mathrm{KSC}$ & 129 & 124.57 & -9 \\
\hline 7. & Main steam temp. & ${ }^{\circ} \mathrm{C}$ & 537 & 533.36 & -1 \\
\hline 8. & HRH steam temp. & ${ }^{\circ} \mathrm{C}$ & 537 & 537.15 & 0 \\
\hline 9. & oxygen & $\%$ & 3.5 & 2.73 & 0 \\
\hline 10. & $\begin{array}{l}\text { Fl.gas temp. at RAH 0/L[left] } \\
\text { Fl.gas temp. at RAH O/L[right] }\end{array}$ & $\begin{array}{l}{ }^{\circ} \mathrm{C} \\
{ }^{\circ} \mathrm{C}\end{array}$ & & $\begin{array}{l}146.23 \\
146.57 \\
\end{array}$ & -8 \\
\hline 11. & Turbine cycle eff. Loss (Other than Ageing) & $\%$ & 0 & & -18 \\
\hline 12. & Carbon in bottom ash & $\%$ & 2 & 2.1 & 0 \\
\hline
\end{tabular}

\subsection{Performance of Condenser}

Condensers are devices in which cooling water is used to condensate the exhaust steam from the steam turbine.

The primary objective of a condenser is to maintain a very low back pressure on the exhaust side low pressure turbine. This enables the steam to expand to a greater extent which results in an increase in available energy for converting into mechanical work. [Shende M.B. et al, 2015]. Following formula is used for calculating condenser efficiency:

Condenser efficiency $=$ rise in temperature of cooling water[Saturation temp corresponding to the absolute pressure in the condenser]-[inlet temp of cooling water]
Table 3 Condenser performance parameters

\begin{tabular}{|c|c|c|c|c|}
\hline Sl.No. & Particulars & Unit & Design & Operational \\
\hline 1. & Vacuum & Ksc & 0.91 & 0.909 \\
\hline 2. & $\begin{array}{c}\text { CW O/L } \\
\text { Temp }\end{array}$ & ${ }^{\circ} \mathrm{C}$ & 38.4 & 39.45 \\
\hline 3. & $\begin{array}{c}\text { CW I/L } \\
\text { Temp }\end{array}$ & ${ }^{\circ} \mathrm{C}$ & 30 & 28.9 \\
\hline 4. & $\begin{array}{c}\text { LPT Exhaust } \\
\text { Temp }\end{array}$ & ${ }^{\circ} \mathrm{C}$ & 43.2 & 43.5 \\
\hline 5. & $\begin{array}{c}\text { CW temp. } \\
\text { rise }\end{array}$ & ${ }^{\circ} \mathrm{C}$ & 10 & 10.54 \\
\hline
\end{tabular}

\section{Efficiency Calculation}

Step- 1) DTCHR of $210 \mathrm{MW}$ is $2021 \mathrm{kcal} / \mathrm{kwh}$. GTCHR $=24+2021$ $=2045 \mathrm{kcal} / \mathrm{kwh}$ 
Step-2)

Turbine $\eta=\frac{860}{\text { turbine heat rate }} \times 100$

Step -3)

Turbine $\eta=42.05 \%$

\section{UHR=GTCHR/Boiler Efficiency \\ $=2045 / 86.53$ \\ $=2363 \mathrm{kcal} / \mathrm{kwh}$}

Step -4)

Condenser $\eta$

$=$ Rise in cooling water temperature

LPT exhaust temp - Inlet temp. of c.w

$=0.7219$

$=72.19 \%$

Step-5)

Plant efficiency $=\frac{860}{\text { Unit heat rate }} \times 100$

$=35.9 \%$

\section{Cost Benefit Analysis}

Heat rate is helpful in determining how efficiently any unit is being operated, as lower is the heat rate higher will be the operational efficiency. For identifying the performance of either any unit or unit equipments, heat rate deviation is used instead of heat rate. This heat rate deviation can be converted into cost for calculating annual fuel cost. Cost calculation using heat rate instead of heat rate deviation is often overlooked in a thermal power plant.

Heat rate deviation in helpful in identifying the problem in any equipment or auxiliary, and its magnitude is helpful in assigning priority level to these problems. Since, heat rate deviations can be converted into cost, it is helpful in solving the highest priority problems first so as to minimize the amount of fuel consumption.

Cost of heat rate deviation $=$ heat rate deviation $\times$ net generation $\times$ fuel cost [Robert J. et al, 2000]

An increase in heat rate results in increasing the fuel consumption whereas any decrease in heat rate results in reduction of fuel requirement for producing a given number of KWH of energy. Heat rate also plays a key role in any purchasing decision, be it fuel, oil, or any equipment, etc.

Table 4 Cost of heat rate deviation

\begin{tabular}{|c|c|c|c|c|}
\hline $\begin{array}{c}\text { Sl. } \\
\text { No. }\end{array}$ & Particulars & Unit & $\begin{array}{c}\text { UHR Loss } \\
\text { (Kcal/kWh) }\end{array}$ & $\begin{array}{c}\text { Cost of } \\
\text { heat rate } \\
\text { deviation } \\
\text { (Rs) }\end{array}$ \\
\hline 1. & Partial loading & $\%$ & 0 & 0 \\
\hline 2. & $\begin{array}{c}\text { LPT. exhaust steam } \\
\text { temp } \\
\text { Cond. } \\
\text { backpressure }\end{array}$ & Deg C & -2 & -34.06 \\
\hline 3. & D.M. make up & T/Hr & -11 & -187.33 \\
\hline 4. & Final F.W. temp. & Deg C & 0 & 0 \\
\hline
\end{tabular}

\begin{tabular}{|c|c|c|c|c|}
\hline 5. & R.H. spray & T/Hr & -12 & -204.36 \\
\hline 6. & Main steam press. & KSC & -9 & -153.27 \\
\hline 7. & Main steam temp. & Deg C & -1 & -17.03 \\
\hline 8. & HRH steam temp. & Deg C & 0 & 0 \\
\hline 9. & Oxygen & $\%$ & 0 & 0 \\
\hline 10. & $\begin{array}{c}\text { Fl.gas temp. at RAH } \\
\text { O/L[left] } \\
\text { Fl.gas temp. at RAH } \\
\text { 0/L[right] }\end{array}$ & Deg C Deg C & -8 & -136.24 \\
\hline 11. & $\begin{array}{c}\text { Turbine cycle eff. } \\
\text { loss (Other than } \\
\text { Ageing) }\end{array}$ & $\%$ & -18 & -306.54 \\
\hline 12. & $\begin{array}{c}\text { Carbon in bottom } \\
\text { ash }\end{array}$ & $\%$ & 0 & 0 \\
\hline 13. & Total & & -61 & -1038.83 \\
\hline
\end{tabular}

In above table, cost of heat rate deviation of each parameter has been calculated where,

Net generation= gross generation-auxiliary power consumption

$$
=195.41 \mathrm{MW}
$$

Fuel cost $=$ Rs $610 /$ ton or Rs $87.2 / 10^{6} \mathrm{kcal}$

-ve sign of heat rate deviation indicates the better performance of plant and +ve sign indicates poor performance of plant.

From table, we get cost of heat rate deviation $=$ Rs 1038.83

$(-)$ sign indicates the cost saving in fuel.

Annual cost of heat rate deviation $=$ heat rate $\times$ fuel cost $\times$ unit rating $\times$ PLF $\times$ hrs in a year

[Palo Alto et al, 2014]

$$
=2452 \times \frac{87.2}{10^{6}} \times 210 \times 1000 \times 1.01 \times 8760
$$

$=$ Rs 397,266,299.9 $/ \mathrm{yr} \quad$ (as on $1^{\text {st }}$ April, 2016)

$=2452 \times \frac{87.2}{10^{6}} \times 210 \times 1000 \times 0.69 \times 8760$

$=$ Rs 271,399,749.5 $/ \mathrm{yr}$ (for financial year 2015-16)

If $1 \%$ heat rate is reduced then annual cost of fuel will be-

Annual cost of heat rate deviation

$$
=2452 \times \frac{87.2}{10^{6}} \times 210 \times 1000 \times 1.01 \times 8760 \times .01
$$

$=$ Rs 3,972,662.99 $/$ year (as on $1^{\text {st }}$ April, 2016)

Annual cost of heat rate deviation

$=2452 \times \frac{87.2}{10^{6}} \times 210 \times 1000 \times 0.69 \times 8760 \times .01=\mathrm{Rs}$

$2,713,997.49$ / year (for financial year 2015-16)

This is the annual saving in fuel cost just by $1 \%$ improvement in heat rate.

Some the areas where heat rate improvement can result in tremendous improvement of overall heat rate are mentioned below.

- By giving heat rate awareness training to operation staff:- $0.5 \%$ to $1 \%$

- Heat rate information availability to plant personnel:- $0.5 \%$ to $1.5 \%$

- By proper utilization of controllable losses information by operation staff:- $0.75 \%$ to $1 \%$

- By conducting routine testing program at regular intervals:- $0.7 \%$ to $2 \%$

- By increasing the routine monitoring of feed water heater performance:- $0.3 \%$ to $0.6 \%$

- By optimizing soot blower operation:- $0.7 \%$ 
Maximum improvement in heat rate ranges from approximately 3 to $5 \%$ for this unit. This could save annual cost of fuel from Rs 8,141,992.48/yr to Rs 13,569,987.48 /yr (for 2015-16 financial year).

Recovery of heat rate by $20 \mathrm{kcal} / \mathrm{kWh}$ increases the output by5 MW (0.12 MU) per day. This will increase the revenue by 15.65 lakhs per day per unit.

\section{Discussion}

\subsection{Dry flue gas loss optimization}

The dry flue gas loss depends on two factors. They are excess air and air heater gas outlet temperature.

\subsubsection{Excess air control}

For every $1 \%$ reduction in excess air there is approximately $0.6 \%$ rise in efficiency. Excess air is monitored by $\mathrm{CO}_{2}$ and $\mathrm{O}_{2}$ measurements at air heater inlet.

Air infiltration should be controlled to limit this loss. Various methods like oxygen analyzers, draft gauges and stack damper control can be used to calculate readings of excess air.

\subsubsection{Air heater gas outlet temperature optimization:-}

It should be lowest from overall efficiency point of view, whereas should be high on account of corrosion problem.

For Indian coals having low percentage (approx $(0.5 \%))$ of Sulphur, this specified temperature is of the order $130^{\circ} \mathrm{C}$. A $22^{\circ} \mathrm{C}$ rise in air heater gas outlet temperature reduces boiler efficiency by $1 \%$.

Some of the causes of his gas outlet temperature are lack of soot blowing, high excess air, low final feed water temperature, improper combustion, poor milling, air in leakage before the combustion chamber, etc. Though in the short run, low air heater gas outlet temperature improves efficiency; in the long run it can result in low boiler efficiency because of deposition on its elements and corrosion.

Most obvious cause of low air heater gas outlet temperature is lighting and firing a cold boiler. Its remedy is to bypass the air heater until the gas temperature is high enough to permit normal operation. It's another reason is air leakage across air heater seals. The rate of air leakage varies with the square root of the differential pressure across the air heater.

\subsection{Wet flue gas loss optimization}

Losses due to moisture in fuel, hydrogen in fuel and moisture in combustion air depends on final gas outlet temperature. These losses decrease slightly with fall in boiler output.

Power plant waste heat can be used to remove moisture before pulverization process which can provide heat rate and emission benefits, reduce maintenance cost and it will also be reducing cooling water makeup requirement.

\subsection{Carbon in ash loss optimization}

This loss depends on the fineness of pulverized fuel, excess air and combustion condition. If combustion is not monitored properly the loss which is normally about $1 \%$ may be as high as $4-5 \%$. Some of the causes of high carbon content in ash are coarse grinding, mal adjustment of flame, unequal loading of different mills, incorrect primary air temperature, etc.

Whereas over grinding of fuel can lead to low carbon in ash and its causes are exhauster speed too low, rich fuel/air mixture, separator speed too high, mill in need of adjustment, etc.

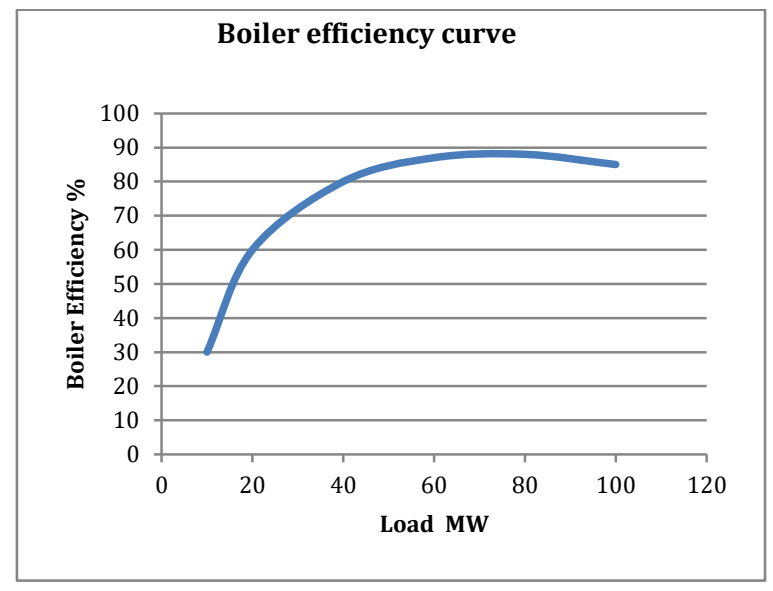

Figure-2 Boiler efficiency curve

\subsection{Turbine efficiency optimization}

Turbine cylinder efficiency is around 85\%, 92\% and $80-85 \%$ for HP, IP and LPT respectively. Some of the losses that occur in stem path are loss due to solid particle erosion of moving blades, solid particle erosion and roughness of diaphragm blades and damage of the fins of shaft blades.

Optimization of these losses can help in turbine cylinder efficiency improvement. It can be done by taking measures like increasing the turbine exit annulus area, lowering the kinetic energy of the steam as it leaves the last stage blade, steam blowing should be done after boiler Overhauling, Replacement of all Tip Seals, Inter stage \& Gland Seals in every capital overhauling, Strict \& vigilant control on water chemistry, using additives in feed water to reduce surface tension due to formation of water droplets, etc.

\subsection{Condenser vacuum optimization}

Heat loss from thermal power plant is mainly due to heat rejection through the condenser. A difference of $5 \%$ in cooling water inlet temperature changes unit heat consumption by around $1 \%$. It can be done by following ways: 
High cooling water inlet temperature leads to higher saturation temperature and corresponding rise in condenser saturation pressure (i.e. lower condenser vacuum) for a design specified cooling water temperature rise and terminal temperature difference. Hence low inlet temperature values must be maintained.

Reduced cooling water flow rate shall increase the cooling water temperature rise, which leads to higher saturation temperature at design terminal temperature difference and corresponding saturation pressure.

Condensate level in the hot well if gets more than design value, will lead to improper heat transfer because it will cover some of the cooling water tubes thereby making them unavailable for condensation.

Internal and external tube deposit causes high terminal temperature difference which can be minimized by on-line condenser tube cleaning and better de-mineralized water quality management respectively.

Air ingress results in poor heat transfer co-efficient which increases condensing temperature in order to get heat across air barrier, this makes the vacuum worst. It can be avoided by frequent leak detection test and effective steam sealing of low pressure turbine.

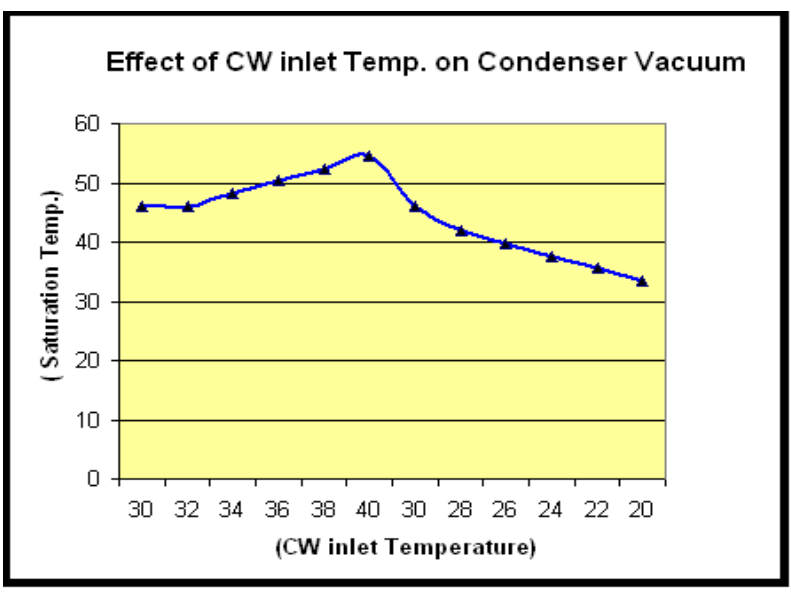

Figure 3 Effect of cooling water inlet temperature on condenser vacuum

\subsection{Steam temperature control}

One of the techniques used to prevent excessively high steam temperatures at the inlets to the high pressure and intermediate pressure turbines is to spray liquid $\mathrm{H} 2 \mathrm{O}$ into the steam. Referred to as attemperating spray, these liquid flows are taken from the turbine cycle and result in an increase in heat rate. Consequently, attemperating spray flow rates should be the minimum flow rates needed to control steam temperatures to the design levels. If main steam and hot reheat steam were at lower than desired temperatures, while both main steam and hot reheat attemperating sprays were in operation, then it will result in heat rate penalties due to low steam temperatures and to use of attemperation when it was not needed. Thus an upgrade to the steam temperature controls and perhaps repair of leaking flow control valves would be needed to prevent this type of loss.

\subsection{Scaling and soot abatement}

Factors favoring soot formation are high temperature and shortage of oxygen. Elevated stack temperature indicates soot deposition as well as scaling on the water side. With every $22^{\circ} \mathrm{C}$ increase in stack temperature, $1 \%$ efficiency loss occurs in boilers. Practices like periodic off-line cleaning of radiant furnace surfaces, boiler tube banks, economizers and air heaters are necessary to remove scaling and soot formation.

\section{Result}

Following results have been concluded

- $5 \%$ change in excess air changes dry flue gas loss by $1 \%$.

- Radiation and convection losses are around 0.4 to $1 \%$

- A difference of $5 \%$ in cooling water temperature changes the unit heat consumption by $1 \%$.

- Condenser vacuum should be maintained at 0.89 to $0.9 \mathrm{ksc}$.

- By combustion optimization heat rate reduction in the range of $0.5 \%$ to $1 \%$ can be achieved.

- By upgrading steam turbine generators and enhancement of auxiliary component can lead to improvement of 2 to $4 \%$.

- $\quad$ By reducing steam, water and internal leakage heat rate can be improved by $0.5 \%$.

\section{Conclusion}

Also following critical parameters must be observed so as to further increase the plant performance:

- Main steam temperature and pressure should be increased

- Re-heater spray should be decreased

- Condenser vacuum should be decreased

- Turbine cylinder efficiency should be increased

- Dry flue gas loss should be decreased

- Un-burnt carbon percentage should be decreased

- Moisture in fuel should be decreased

- Moisture in combustion air should be decreased

- Heat rate should be decreased

- $\quad$ Plant should be operated at full load for maximum efficiency.

\section{Future Scope}

By regular heat rate improvement program, efficiency can be increase to an extent. Following aspects can be further studied to improve plant efficiency. They are- 
- Air ingress deteriorates the heat transfer coefficients. Thereby increasing the condensing temperature in order to get heat across air barrier. This makes the vacuum worse.

- $\quad$ Re heater pressure drop adversely affect the HPT exhaust pressure, thereby affecting the IPT inlet pressure.

\section{References}

NTPC manual file http://www.ntpc.co.in/

Nag, P. (2002), Basic and applied Thermodynamics.

Sethi,V.K (2012), Power Generation TechnologyConventional Thermal To Green Mega Power.

S. and D. Adhyaru (2011), Boiler efficiency analysis using direct method, 2011 Nirma University International Conference on Engineering, IEEE.

Sankar B.S.S and Rao G.V (2015), Performance Analysis and Energy Audit Based on Dry Flue Gas Loss by using Modern Soot Blower in Thermal Power Plant, International Journal of Thermal Technologies, Inpressco, vol.5, No.4.

Dhanre G.T, Dhanre U.T. and Mudafale K., (2014), Review Paper on Energy Audit of a Boiler in Thermal Power Plant, IJSR, vol.2, issue 6, Oct-Nov 2014.
Kurkiya R and Chaudhary S (2012), Energy Analysis of Thermal Power Plant , International Journal of Science \& Engineering Research Volume (IJSER), VOL-3, ISSUE-7, July-2012

Kumar, C. K. and G. S. Rao (2013). Performance analysis from the energy audit of a thermal power plant, International Journal of Engineering trends and Technology (IJETT), ISSN: 2231-5381.

Shende M.B, Shinde N. N., Desai S. B.and Wagh M.M., (2015), Performance of Thermal Power Plant on System Based, IRJET, vol.2, issue.4, july-2015

Robert J.Tramel (2000), Heat rate improvement guidelines for Indian Power Plants, volume 1, 2United States Tennessee Valley Authority , June 2000

Palo Alto (2014), Range and Applicability of heat rate improvements, EPRICA:2014, 3002003457

Performance report of financial year, 2015-16

Vinchurkar A.G, Lakhe R.R and Shrivastava R.L (2014) Energy efficiency analysis of thermal plant boilers, IJRME vol 2,issue 3,May-June-2014.

Singh, S. P., Philip G., Singh S.K. (2014), Effect of condenser vacuum on performance of a Reheat Regenerative $210 \mathrm{MW}$ Fossil-Fuel based Power Plants, IJETAE, vol 4,issue 1,Feb2014 